\title{
"NEW PSYCHIATRY" AND TRADITIONAL HEALING IN KYRGYZSTAN: ATTEMPTS TO DEVELOP CULTURALLY SENSITIVE AND COMMUNITY-BASED TREATMENT
}

\author{
DANUTA PENKALA-GAWĘCKA
}

\author{
INSTITUTE OF ETHNOLOGY AND CULTURAL ANTHROPOLOGY \\ ADAM MICKIEWICZ UNIVERSITY IN POZNAŃ
}

\begin{abstract}
Healthcare in post-Soviet Central Asian countries, and mental healthcare in particular, has still preserved many characteristics of the previous Soviet system. In the Kyrgyz Republic, a wide-ranging reform of the healthcare system, which started in the second half of the I990s, has not included psychiatric services in its priorities. In the face of severe deficiencies in the system, such as an over-institutionalisation of mental healthcare and a lack of adequate financing, a group of local psychiatrists, aware of the standards of contemporary psychiatry, have tried to implement an approach promoting culturally sensitive and community-based treatment of mentally ill patients. They notice a great popularity of traditional healers and their role in local communities, based on a worldview shared with their patients and competence in values and norms of social life. Moreover, these psychiatrists understand that healers' interventions can be effective in the cases of non-psychotic mental health disorders, and attempt to develop some kind of cooperation with Kyrgyz healers, especially in crisis situations. In this article, grounded in the publications of this group of psychiatrists and my own fieldwork in Bishkek between $201 \mathrm{I}$ and 2013, I discuss these achievements and show how globally promoted ideas and directives of contemporary psychiatry have been adapted to the local conditions.
\end{abstract}

System opieki zdrowotnej w postsowieckich krajach Azji Środkowej, a w szczególności system pomocy psychiatrycznej, zachował wiele cech medycyny sowieckiej. Reformy systemu medycznego, prowadzone na szeroką skalę od połowy lat 90. ubiegłego wieku w Republice Kirgiskiej, w niewielkim stopniu objęły sektor zdrowia psychicznego. Wobec poważnych niedostatków systemu, takich jak nadmierna instytucjonalizacja opieki psychiatrycznej i brak odpowiedniego finansowania, grupa miejscowych psychiatrów, świadomych standardów współczesnej psychiatrii, zaczęła promować i wprowadzać w życie idee kulturowo wrażliwej i opartej na współpracy społeczności opieki nad chorymi psychicznie. Dostrzegli zjawisko wielkiej popularności tradycyjnych uzdrowicieli i ich rolę w lokalnych społecznościach, której podstawą jest podzielana z pacjentami wizja świata, a także znajomość wartości i norm życia społecznego. Ponadto przyznali, że praktyki uzdrowicieli mogą być skuteczne w przypadku niepsychotycznych zaburzeń psychicznych, a także podjęli pewne formy współpracy z kirgiskimi uzdrowicielami, szczególnie w sytuacjach kryzysowych. W niniejszym artykule, opartym 
na publikacjach tej grupy psychiatrów oraz własnych badaniach terenowych prowadzonych w Biszkeku w latach 20II-20I3, rozważam te osiągnięcia i pokazuję, w jaki sposób promowane w skali globalnej idee i dyrektywy współczesnej psychiatrii adaptowane są do lokalnych uwarunkowań.

Keywords: psychiatry, mental healthcare, traditional healing, culturally sensitive treatment, community-based treatment, cooperation between psychiatrists and healers, Central Asia, Kyrgyzstan

\section{INTRODUCTION}

During anthropological research in Kyrgyzstan, shortly after starting my fieldwork in Bishkek in 20II, I learned about some psychiatrists who were interested in the practices of local traditional healers ${ }^{1}$, observed their work and recognised the abilities of particular healers to help people. Examples of such an attitude, which sometimes leads to attempts at cooperation between psychiatrists and healers in various socio-cultural settings, can be found in the existing literature, mainly within the field of transcultural psychiatry. I wondered, however, how this trend had emerged in Kyrgyzstan's psychiatry, what its specificity in the local context was and whether any forms of cooperation with healers had developed.

Those issues did not lie at the heart of my research, which focused on people's perceptions of health and illness, and their health-seeking strategies and practices in the context of urban medical diversity. I spent three fieldwork seasons in Bishkek between $201 \mathrm{I}$ and $2013^{2}$, conducting ethnographic research based mainly on talks and to a lesser extent on semi-structured interviews with "ordinary" people, healers, doctors and other biomedical professionals. However, as my interest in the above-mentioned questions developed, I found an opportunity to talk with two female psychiatrists professors, belonging to different age categories (one was retired, although still worked part time, the other was younger and fully active). This article is partly grounded in the information that I received from them ${ }^{3}$, partly in the literature on Soviet psychiatry and especially in the articles describing the contemporary status of psychiatry and psychology in the Kyrgyz Republic. I was particularly interested in new approaches in Kyrgyzstan's psychiatry, which give attention to socio-cultural particularities, including certain features of local healing.

I The word "traditional" should, in actuality, be placed in quotes, since healers' ideas and practices are highly hybridised. I decided to omit quotation marks in the text for reasons of convenience.

2 This research was supported by the National Science Centre in Poland [Narodowe Centrum Nauki], grant No. NNiog i86440.

3 We mainly talked about the role of healers and psychiatrists' attitudes towards them. 
First, I briefly present main characteristics of Soviet psychiatry, while being aware of the danger of unjustified generalisations and stereotyping. The next section shows the picture of psychiatry and practices of mental healthcare in post-Soviet Kyrgyzstan, focusing on its current problems, efforts to implement reforms and the constraints encountered, which hinder the fuller implementation of standards of contemporary psychiatry. Subsequent parts of the article deal with its main topic - local responses to the globally prevailing trends which promote culturally sensitive, community-based treatment and social support for mentally ill patients. I discuss the standpoint and practical efforts of a group of psychiatrists in Kyrgyzstan who stress the importance of social and cultural factors in shaping people's attitudes to mental disorders, and call for implementing new approaches within mental healthcare services. I focus on interesting examples of such endeavours, namely appreciation of the role of healers in the locally-provided care for people with mental health problems and attempts to develop cooperation with these non-biomedical practitioners in particular situations. These developments reveal how global ideas about community-based treatment of the mentally ill have been adopted to the local circumstances. This process should be viewed in the wider context of the social, economic and political changes following the collapse of the Soviet Union.

\section{SOVIET PSYCHIATRY - COMMON FEATURES AND LOCAL DIFFERENCES}

Several specific features of Soviet psychiatry are commonly presented in the literature discussing its development and subsequent changes after the dismantling of the USSR, in Russia and other newly independent countries. In general, psychiatry and mental healthcare conformed to the Soviet model of highly centralised, hierarchical and administratively organised medicine, (Field 2002; see also Borovitz and Atun 2006). Among the main, often mentioned characteristics of Soviet psychiatry, there are: the centralisation of psychiatric policy $y^{4}$; the use of psychiatry as an instrument of political repression; a prevailing Pavlovian and anti-Freudian conceptual orientation; work (or "occupational therapy") considered as a primary means of treatment; isolation from the trends of western psychiatry (Raikhel and Bemme 2016, I55). In addition, it is pointed out that Soviet mental health care was based on large, specialised psychiatric hospitals which, "with some exceptions [were] overcrowded, understaffed, and in poor repair" (Probes et al. 1992, 69). Much scholarly attention has been paid to psychiatric hospitals of the "special type", resembling penal facilities and operated by the Ministry of Internal Affairs, meant for political dissidents who were given psychiatric diagnoses. Although researchers have indicated that psychiatric abuse observed during Soviet times 
should not be understood as the result of bad psychiatry, but of bad politics (Probes et al. 1992, 75) and many questions regarding the political use of psychiatry remain unanswered, this issue strongly affects the field of psychiatry's reputation in the former USSR (Raikhel and Bemme 2016, 158-159) .

Importantly, recent studies show that "sciences of the mind and brain" - the so called psy-ences or psy-disciplines (psychiatry, psychology, among others) - were "surprisingly heterogeneous" under socialism, and the changes observed in Soviet times were "shaped not simply by political interference in science, but by a range of conceptual and social dynamics" (Raikhel and Bemme 2016, I55-156). For example, even during the dominance of Pavlovian psychiatry of the 1950s - represented mainly by the Moscow school - competing theories and "schools" emerged, such as the Leningrad school, "which placed a greater emphasis on environmental and psychosocial factors in the development of mental illness" (Raikhel and Bemme 2016, 157) ${ }^{6}$. This approach was closer to the ideas of social (or socialised) medicine, which were characteristic of the early years of the Soviet Union (see also Field 2002).

It is often stressed in the literature that psychology did not get much attention during Soviet times and it remained on the margins of dominant psychiatry. As Lawrence Probes et al. state, "there were comparatively few psychologists in the USSR (...) and they played only a minor role in clinical psychiatry" (I992, 68). It was a "clinicaldiagnostic" approach that permeated Soviet psychiatry and it was only in the final years of perestroika that psychology began to receive more recognition (Raikhel and Bemme 2016, I57, I64). One of my interlocutors - a psychiatrist and psychologist, Galina Mikhailovna ${ }^{7}$ recalled that after completing a course in psychiatry at the Medical Academy in Frunze (today's Bishkek) she was lucky to have been directed to Moscow to undertake specialisation in psychology in the early I970s, when it was treated as a discipline entirely separate from medical studies. Generally, psychotherapy was considered a part of "small psychiatry", which dealt with "mild" psychic disorders, such as neuroses or personality disorders, while "big psychiatry" treated schizophrenia, dementia, etc. (Molchanova, Kim et al. 2009, 27I).

When discussing Soviet "psy-disciplines", we should consider the differences in their trajectories in various parts of the USSR. Although a lot of research accentuates the uniformity of healthcare in all the constituent Soviet republics, due to the highly

5 Editors of the first, significant book on the history of psychiatry under communism in the Soviet Union and Central and Eastern Europe, Mat Savelli and Sarah Marks, point out that "the intensity of debate regarding the issue of psychiatric abuse has (...) deflected attention away from attempts to understand the development of psychiatry in Eastern Europe and the USSR in a wider context" (Savelli and Marks 2015, 6).

6 Lawrence Probes et al. (1992, 70) also notice that even at that time some branches of psychiatry progressed in the USSR, e.g. hypno-suggestive therapy for psychosomatic disorders or alcoholism.

$7 \quad$ I have changed the names of my interlocutors to preserve their anonymity. 
centralised and standardised policies (Field 2002, 68), a closer look at particular cases might reveal local specificities, despite common characteristics. Such differences could be observed in Central Asia, especially during the earlier stages of Soviet rule. An interesting and particularly thorough overview, provided by Alisher Latypov (2010), shows the transformations of mental healthcare in Tajikistan, from the time of the Russian Empire, through the long Soviet period and into the first decades of independence. The author discusses, among other things, severe difficulties in the establishment of the psychiatric profession (and biomedical healthcare in general) in Soviet Tajikistan, not only because of the lack of physicians trained as psychiatrists, but primarily because of people's distrust of non-native doctors, and the authority of tabibs, religious and spiritual healers among Tajiks (Latypov 20I0, 426-427). After harsh attacks against mullahs and healers during the Soviet anti-religious and modernisation campaign, the first state psychiatric hospital was established in 194I, close to Stalinabad. Similar processes took place in other regions of Central Asia, such as Kazakhstan (see Michaels 2003) and Kyrgyzstan.

It is necessary to emphasise the importance of the evacuation of leading Russian physicians, including psychiatrists, to Central Asia during World War II. In Kyrgyzstan, older people still remember and highly value doctors who were transferred to Frunze during the war. Latypov points out that the arrival of experienced psychiatrists enabled "the formal foundation" of psychiatry in Tajikistan (Latypov 20I0, 428). It might also have led to the increased uniformisation of mental healthcare ${ }^{8}$. The author comments on this, describing standardised psychiatric education, therapeutic methods and institutions which developed between I960s and 1980s, as well as psychiatric abuse, not only in its political dimension, but also in the everyday practices of the hospital's personnel (Latypov 20IO, 432-434). In another article he reveals the ways in which psychiatry was used by the Soviet regime in political campaigns in Central Asia, and focuses on the construction of a psychiatric category called narkomania (drug addiction) presented as a regional problem, specific in the "backward" peripheral areas of the USSR (Latypov 20I5; see also Latypov 20II).

In the Kirghiz Soviet Socialist Republic, according to Molchanova, Kim et al. (2009, 27I-272), psychotherapy was developed within the field of "medical psychology" in the I960s and I970s, thanks to Nikolay Kantorovich, a follower of the Leningrad school and the head of the Department of Psychiatry at the Medical University in Frunze. The methods of treatment included hypnotherapy, meditation and so called rational therapy (a Soviet version of cognitive therapy). Jenishbek Nazaraliev, a psychiatrist who 
designed his own, original methods for treatment addicts in the I990s, notes that in the late I970s and early I980s a local school of therapy for drug-dependent and alcoholdependent patients, grounded in psychotherapy, was taking shape in Kyrgyzstan. In his words, a group of local scholars

"put forward, for the first time in the Soviet Union, a comprehensive programme for the prevention of alcoholism, drug addiction, toxicomania and smoking among the young people" (Nazaraliev 2003, 73).

Hence, it can be claimed that apart from universal features, there were also particular trajectories of Soviet psychiatry in Central Asian region.

\section{PSYCHIATRY AND MENTAL HEALTHCARE IN THE KYRGYZ REPUBLIC - AN OVERVIEW}

After the disintegration of the Soviet Union the newly independent post-Soviet countries encountered enormous economic and social difficulties connected with fundamental political changes. A dramatic deterioration of the inherited Soviet healthcare system belonged to these pitiful consequences. However, researchers have emphasised that deficiencies of this system were already apparent earlier, during the "late socialism" and perestroika. In fact, it can be compared to a statue with feet of clay: highly centralised, underinvested - as a "non-productive" sector, with big hospitals, overspecialisation and weak primary care, shortages of equipment and pharmaceuticals, and prevailing quantitative indices (Field 2002; Borowitz and Atun 2006). Following the breakup of the USSR, a drastic decrease in funding led to the collapse of the healthcare infrastructure and a severe worsening of epidemiological situation and health outcomes in many regions, including Central Asian republics. The need for substantial improvement was obvious, and Kyrgyzstan was one of the first countries in the region to start wide-ranging healthcare reform. The results of three subsequent reform programmes, such as the development of family medicine and new financing mechanisms, have been positively assessed by international experts (Borowitz and Atun 2006, 434; Ibraimova et al. 20IIa, 20Irb). Despite this, many problems in the healthcare system of Kyrgyzstan are still noticeable, including underfunding, uneven distribution of medical personnel and institutions in the country, poor quality of training, corruption and mass economic emigration of doctors and other medical staff. In addition, as I observed during my own research in Bishkek, there was a striking contrast between the positive evaluations of the reforms by specialists, on the one hand, and people's assessments on the other hand, which were generally negative, and distrust of doctors evidently prevailed (Penkala-Gawęcka 20I4a, 20I6).

With regard to the situation of psychiatry and mental healthcare in the Kyrgyz Republic, the reform in this sector has not been successful thus far. Programmes of 
reforms implemented between 1996 and 2016 did not include mental health services in their priorities (WHO-AIMS Report... 2008, 3I). It is significant that the report on Kyrgyzstan's healthcare system in the Health in Transition series devoted only a few pages to mental healthcare, and the overall assessment was: "the quality of mental health care remains poor" (Ibraimova et al. 20Ira, 93) ${ }^{9}$. Local specialists complain about continued government neglect of numerous problems affecting psychiatric care. With the dissolution of the Soviet Union the situation of mental healthcare in Central Asia drastically worsened and among the wide range of pressures, a lack of funding was the most intense. While reporting on the collapse of psychiatric care in Tajikistan, Latypov used the wording "the humanitarian catastrophe in mental institutions" (2010, 434). Actually, the situation in this country has been perhaps the worst in the region, due to unrest and a civil war between 1992 and 1997 and its consequences ${ }^{10}$. The collapse of the previous system had, however, also severe consequences in Kyrgyzstan - for instance, it was noted that the mortality rate among patients at the Chim-Korgon psychiatric hospital near Bishkek increased by $50 \%{ }^{11}$.

As Eugene Raikhel and Dörte Bemme (2016, I6I) note, mental healthcare has remained highly institutionalised in most of the former Soviet states. With regard to Kyrgyzstan, Ainura Ibraimova et al. (2OIIa, 93) point to an overemphasis on large inpatient facilities, which work inefficiently ${ }^{12}$. This issue is also discussed by local psychiatrists who likewise notice deficiencies of the inherited system. For example, Molchanova et al. (2015, I3) write that it is "overly centralised (...) and still resembles the mental health care system in the Soviet Union", and complain about the lack of adequate financing for improving its structure ${ }^{13}$. Krassimir Kanev, the author of one of the reports, maintains that the opinion on excessive institutionalisation as the most significant problem of mental healthcare system in Kyrgyzstan was shared "almost

9 Strikingly enough, in an earlier report on healthcare in Central Asia "mental health" was mentioned only once, in the article on reforms. The authors note that the rapidity of social change in the region "is (...) likely to have an impact on levels of mental health, although there has been no specific analysis of this issue" (Savas et al. 2002, 8I). Another report, by Ibraimova et al. (201rb), which describes Kyrgyzstan's success in healthcare reform, does not mention mental healthcare at all.

IO Latypov provides a broad list of the challenges that faced the mental health service and concludes that, as a result, "those unfortunate enough to have been inpatients at psychiatric facilities during this period, stood only a 50\% chance of surviving the conditions" and adds that "this period saw an increase in the incidence of such conditions as post-traumatic stress disorder, anxiety and depression" (Latypov 2010, 437-438).

II According to statistics from I99I to 2013, quoted by Molchanova (2014a, 23, 26).

I2 It is exemplified by a low bed occupancy rate $-66 \%$ in 2007 (Ibraimova et al. 20IIa, 93).

I3 As they stress, "the majority of psychiatric services (...) remain concentrated within the general area of Bishkek, and particularly beneath the umbrella of the Republic Center of Mental Health" (Molchanova et al. 2015, I3). 
unanimously by government representatives, users and the progressive professional community", whom he interviewed (Kanev 20I2, 6).

The inadequate number of psychiatrists poses another challenge to the functioning of mental healthcare. According to the data reported by Molchanova et al. the number of psychiatrists in the Kyrgyz Republic decreased from 250 in 2001 to 53 in 2015 , and among them there were only six child psychiatrists (down from 33 in 200I). Such a dramatic decrease is mainly due to the mass emigration of medical doctors, including psychiatrists, and the low popularity of this specialty among medical students (Molchanova et al. 2015, I3). The WHO report on mental healthcare in Kyrgyzstan also noted that "psychiatry lost a majority of qualified specialists (migration to other countries, leaving for other structures)", while the demand for psychiatric aids increases (WHO-AIMS Report... 2008, 30, 3I). What is striking is that local psychiatrists often lament the very low prestige of their profession. In Molchanova's words "mental health care specialists in KR [Kyrgyz Republic] are stigmatized even more than patients with mental disorders" (2OI4a, 26). Supposedly, this is the result of the political abuse of psychiatry in the Soviet times, as Reikhel and Bemme argue, claiming that its

"aftereffects for the profession's reputation in Russia - and elsewhere in the post-socialist world - have been longstanding and profound" (Reikhel and Bemme 2016, I59).

In addition, this problem should be considered in the wider context of a significant decrease in the level of trust for doctors in general, which is evident in Kyrgyzstan (Penkala-Gawęcka 20I4a, 20I6) and other countries of Central Asia, and observable in different post-Soviet states as well (for Russia, see e.g. Aronson 2007). As Molchanova puts it, "increased stigmatization of psychiatrists and psychiatry itself" is also due to the activities of several NGOs, fighting against psychiatrists under the slogan of human rights protection (Molchanova 20I4a, 24). She opposes the "radical" approach represented by those activists, who advocate for the abolition of all mental health institutes (Molchanova et al. 2015, 13), and discusses the position of psychiatrists from the academic sphere, critical of the system but unable to develop a detailed plan for its improvement (Molchanova 20I4a, 24) ${ }^{14}$.

One often addressed problem is the use of outdated treatment schemes, which is mainly caused by the lack of adequate funding. Although the psychiatrists working at the departments of psychiatry at the Kyrgyz State Medical Academy and the Slavonic University in Bishkek have developed clinical protocols recommending innovative models of treatment, only old-fashioned treatment programmes are available in mental health hospitals (Molchanova et al. 20I5, I6). However, according to Ibraimova et al.

I4 In Molchanova's words, the situation of mental healthcare in the Kyrgyz Republic "by the end of 2005 could be described as an active destruction of the old system without a construction of anything new instead" (Molchanova 20I4a, 24). 
(201ra, 93-94), the availability of psychotropic medicines has improved, largely because in 2006 the Additional Drug Package of the Mandatory Health Insurance Fund was introduced for insured citizens.

Another challenge to mental healthcare in Kyrgyzstan, mentioned by local specialists, is "the influx of international experts", which, in their opinion, often results in mutual misunderstandings and discrepancies between the needs of patients and "the globally prescribed interventions" (Molchanova et al. 2015, I6). This is in line with what Raikhel and Bemme (2016, I6I-I62) write about the tensions between local understandings of the effective psychiatric and psychological interventions - especially in crisis and conflict situations - and models offered by external experts, promoting global standards ${ }^{15}$. On the other hand, psychiatrists in Kyrgyzstan do admit that a number of successful projects have been supported by international institutions (the Mental Health Initiative of the Open Society Institute, the Soros Foundation Kyrgyzstan, UNICEF and others). For example, outpatient rehabilitation programmes have been developed by NGOs with the support of several external agencies (Ibraimova et al. 2OIIa, 94) ${ }^{16}$. In addition, thanks to the pressure of such organisations as the WHO or the Open Society Foundations, some efforts have been made on the part of the government to improve the system.

Among the positive changes that have been introduced, adoption of the law "On Psychiatric Care and Citizens' Rights to Receive It" in I999, should be noted. However, according to the authors of the report of the Mental Disability Advocacy Center, based on research conducted in Kyrgyzstan in 2003, the review shows that "unless serious measures are taken to meaningfully implement the 1999 Psychiatric Care Law", the mental health system remains overly centralised and based on institutions. Specialists warn that it would continue to deteriorate and the current crisis would even become catastrophic (Mental Health Law... 2004, 5). They argue that "the law has often been inconsistently implemented and in some cases virtually never implemented" and quote examples of violations of basic standards of care and patients' rights in particular mental health institutions (Mental Health Law... 2004, I3; see also Shields and Kabak eds. 2008). Another evaluation, issued later, also points out that these reforms "remained largely on paper" and reports on "systematic violations of patients' rights" (Kanev 2012, 6, 7).

I5 For example, as Raikhel and Bemme state, "calls for further deinstitutionalization often elicit scepticism from local clinicians and observers who fear the result will be an increase in homelessness" (Raikhel and Bemme 2016, 16I).

I6 Several projects providing non-institutional services to psychiatric patients were implemented by the Kyrgyz non-governmental organisation Mental Health and Society, supported by Caritas-France and the Open Society Foundations (Kanev 20I2, 4). Until 2010 the Open Society Foundations were called the Open Society Institute. 
Despite chronic underfunding, some efforts - which included, first of all, increase in out-patient services, educating primary care doctors and integrating psychiatrists into family medicine institutions - have been, at least to some extent, successful (WHOAIMS Report... 2008; Molchanova et al. 2015, I3). These challenges were recognised in the "Mental Health of the Population of the Kyrgyz Republic in 200I-20I0" national programme which was launched by the government in 2000. One of its main goals was to reform over-institutionalised psychiatric services and develop community-based mental healthcare, in accordance with the WHO guidelines (Thornicroft and Tansella 2003). Due to shortages in funding, this programme was suspended (Molchanova et al. $\left.2015, \mathrm{I}_{3}\right)^{17}$, however, thanks to psychiatrists' initiatives and external support, the activities aimed at community-based care have been stimulated. The model of psychosocial support for patients, with the long-term goal of integrating them into their communities, has been developed. This "therapeutic plan" has been implemented by multidisciplinary, mobile teams, which consist of a psychiatrist, a psychologist, a nurse and a social worker. They are involved, among others, in exploring family and clan relations, and family counselling. Importantly, members of the team usually belong to the same ethnic group and often to the same clan as the patient, but in spite of this, as Molchanova (20I4a, 26) claims, it is not easy to reach an agreement between both parties because of widespread resentment towards psychiatrists. Organised since 2006, such teams work in Bishkek, Osh, Karakol, Talas and Naryn and are supported by the Soros Foundation Kyrgyzstan (Molchanova 20I4a; Sadykov and Hosák 2016).

NGOs play an important role in the development of community-based mental health rehabilitation in Kyrgyzstan, especially those which are family-based, i.e. founded by relatives of patients with mental disorders. In Molchanova's words, they "might serve as groundwork for a new set of a culturally-sensitive out-patient and community-based rehabilitation system" (20I4a, 26). The director of the "Family and Society" NGO was one of the founders of first multidisciplinary mobile teams in Kyrgyzstan. Another NGO, "Mental Health and Society", has strongly advocated for mental health patients' rights and helped patients establish their own self-advocacy group.

Psychotherapy and counselling have developed gradually in post-Soviet Kyrgyzstan. However, as specialists point out, "the state psychotherapeutic service is still perceived to be a part of psychiatry", whilst psychological counselling did not exist here until the mid-I990s (Molchanova, Kim et al. 2009, 272, 276). There are psychology

I7 The authors added that the next national programme was under development and would be, hopefully, supported by the World Bank (Molchanova et al. 2015, I3). Actually, the government programme for mental health care of the population of the Kyrgyz Republic for 2018-2030 started in 2018. A new programme on Public Health Protection and Health Care System Development for 2019-2030, called "Healthy Person - Prosperous Country" was launched in 2019 and is supported by the World Bank. According to the government statement, mental health is one of the priority areas in this programme (http://zdrav2030.med.kg/index.php/en/. Access: 15.06.2019). 
departments at some universities (albeit with a focus on theories rather than practice) and specialisation in psychotherapy is offered as a 2-year postgraduate training course at the Kyrgyz State Medical Academy ${ }^{18}$. It is significant that psychologists are rarely found in mental healthcare institutions. Molchanova refers to the Ministry of Health's initiative to introduce posts of psychologists at psychiatric hospitals, which, "attractive in theory, in practice turned into a caricature" because of "an outrageously low salary" (Molchanova 20I4a, 24). Reflecting on the possible future of counselling in Kyrgyzstan, the same author and her colleagues conclude that - despite many challenges - it may increase in importance

"because it is less stigmatized than psychiatry or psychotherapy and it integrates aspects of folk counseling [traditional healing practice] and Western approaches" (Molchanova, Kim et al. 2009, 277).

\section{CULTURALLY SENSITIVE APPROACH AND PSYCHIATRISTS' ENCOUNTERS WITH HEALERS}

Those psychiatrists and psychologists from Kyrgyzstan who are aware of the trends in contemporary global psychiatry and current recommendations of the WHO and other international institutions (Killaspy 2006; Guidance for Commissioners... 2016), have been trying to propagate and implement a "culturally sensitive approach" in their own practice. As I understand from their publications, as well as conversations with two psychiatrists, they place particular emphasis on gaining a thorough knowledge of local cultural traditions and social relations, which is important, in their view, for effective treatment of mentally ill patients.

In the articles dealing with more general issues (e.g. Molchanova, Kim et al. 2009; Molchanova 20I4a), and especially those which describe particular mental health disorders in Kyrgyzstan (e.g. Dobryakov et al. 20I2; Molchanova and Agazade 20I6), the authors provide quite comprehensive accounts of traditional Kyrgyz ideas and practices connected with health and illness, and characterise the specificity of local family relations and wider social organisation ${ }^{19}$. They consider this knowledge necessary for understanding people's attitudes to persons with mental disorders. For instance, great respect for the elders in the family and clan - a deeply rooted and still very important trait of Kyrgyz traditions - is described as a reason for the extremely low number of reported cases of Alzheimer's disease and other forms of dementia,

I8 According to Molchanova, Kim et al. (2009, 274), there is no specialisation in counselling at the departments of psychology, except for the American University in Central Asia (AUCA) in Bishkek.

I9 It should be added that these are almost exclusively accounts of the Kyrgyz culture and society. Apart from the Kyrgyz (67\%), the other major ethnic groups in Kyrgyzstan are Uzbeks (I4\%) and Russians (IO\%). 
especially in rural areas. As Molchanova points out, someone with Alzheimer's disease stays with the family and is treated with care and attention. On the other hand, the low social position of younger women, daughters-in-law (Kyrg. kelin, kelyn) in the family hierarchy, and the youngest one in particular ${ }^{20}$, explains why their disorders are often neglected - in such cases they are rather treated as "bad wives" and may be divorced by their husbands. Whereas, generally, the patriarchal structure of the society results in more attention given to men, older women also usually get support and care (Molchanova 20I4a, 25).

It might be assumed that some of the psychiatrists' accounts, which present lists of particular cultural traits and refer them to attitudes and practices of care for the mentally ill, can lead to the essentialisation of "culture" and support of stereotypes - dangers that are often mentioned by medical anthropologists who discuss the issue of "cultural competency" in the field of healthcare (e.g. Kleinman and Benson 2006). However, when focusing on specific mental disturbances, the authors give much more detailed and nuanced analyses. For example, an interesting paper on depression among pregnant women in Kyrgyzstan (Dobryakov et al. 20I2) takes into account substantial differences between the situation of women in the cities and in rural areas, and shows how the strength of traditional family and gender structures in the latter settings makes for a higher incidence of depression among young Kyrgyz village women. In addition, the authors describe and discuss various, still flourishing "traditional Kyrgyz rituals" connected with pregnancy and birth, pointing out that these rituals attract the attention of perinatal psychologists and psychiatrists, because they function as "specific coping mechanisms" which may prevent depression and anxiety (Dobryakov et al. 2012, 47). Further evidence of such a culturally sensitive approach can also be found in the articles on post-traumatic stress disorder (PTSD) and its "culturally shaped manifestations" in Kyrgyzstan (Molchanova 20I4b; Molchanova and Agazade 20I6). According to the observations of the authors who worked with victims of ethnic clashes in Osh and JalalAbad regions in 20IO, the patients did not usually meet all required criteria for PTSD diagnosis and presented different symptoms (especially somatisation). Explanations for difficulties in applying ASD (acute stress disorder) and PTSD diagnoses have been found in the specific traits of Kyrgyz culture, such as esi (i.e. following strict traditional rules of behaviour), which impose obligations on men of hiding their feelings, not complaining or showing fear (Molchanova and Agazade 2016, 274).

Among often reported cultural peculiarities of the Kyrgyz (similar to other Turkic groups of Central Asia) is their attitude to the world of spirits. It is stressed both in

20 In the patrilineal Kyrgyz society with patrilocal marital residence, a daughter-in-law comes from another clan and lives with her husband and his relatives. The kelin is obliged to do all the housework and obey the other members of the family. In addition, while the older sons with their wives and children may eventually move out and live on their own, the youngest son and his wife must stay with his parents and take care of them. 
anthropological reports and psychiatrists' accounts, that local understandings of the causes of illnesses often refer health disorders to the influence of evil spirits, especially jinns (mentioned in the Qur'an) and albarsty. The latter is a mischievous spirit, known and feared in all Central Asia as a kind of nightmare that torments young women in particular. I was often told about such experiences of my interlocutors or their friends and relatives in Bishkek. Molchanova and Nazim Agazade (2016, 276) describe the characteristics of this creature and the course of its visits, resulting in unpleasant sensations at night, and reveal that patients diagnosed with PTSD after the tragic Osh events ${ }^{21}$ tended to interpret their nightmares just as albarsty's visit.

Locally shared ideas about ancestor spirits (Kyrg. arbak, plur. arbaktar) deserve particular attention. It is striking that from the Kyrgyz point of view, spirits of the dead are continuously present in the lives of their descendants as helpers and protectors, but they can also punish them for improper behaviour or neglecting responsibilities towards arbaktar. As Gul'mira Aldakeeva argues, "respect for the spirits of the dead and relations with them are observed in everyday life and form the core of folk religiosity" $(2009,259)$. These beliefs, expressed in special rituals conducted for arbaktar, together with pilgrimages to sacred sites (Kyrg. mazar) and spiritual healing, constitute what is locally understood as the traditional form of lived, everyday Islam ${ }^{22}$.

In this context, the role and position of spiritual healers, as mediators between the people and the world of spirits, is better understandable. Despite many years of persecution of shamans during Soviet times, shamanic and other healing practices did not disappear, they existed underground and a considerable revival in their popularity has been observed in independent Kyrgyzstan, as well as in the other Central Asian countries (see Duyshembiyeva 2005; Tulebaeva 2009; Penkala-Gawęcka 20I4b, 20I7a, 2017 b; Pelkmans 2017 $)^{23}$. Evidence of their popularity has been provided not only by anthropologists, but also by psychiatrists working in Kyrgyzstan ${ }^{24}$. They point out that according to their statistics,

2I Violent ethnic clashes between the Kyrgyz and Uzbeks took place in southern Kyrgyzstan in 20IO, in Osh and Jalal-Abad in particular.

22 For a thorough discussion on the place of ancestor spirits in the Kazakh religiosity see Privratsky 200I; about the living role of ancestors in Kazakhstan see Dubuisson 20I7. There is also extensive literature (e.g. Aitpaeva 2006 for Kyrgyzstan) dealing with mazars in Central Asia, as sacred sites where close contact with the supernatural (including ancestor spirits) is enabled.

23 It should be noted that this process has occurred during the course of an overall rehabilitation and support for cultural traditions of the titular nations of these countries. See, for example, Sophie Hohmann's in-depth examination of these issues with regard to Uzbekistan (Hohmann 2007, 2010).

24 It is important here to mention that, according to a study conducted in eight post-Soviet countries in 200I, in Kyrgyzstan $25 \%$ of respondents (from the sample 2000) admitted that they had asked healers for help, which revealed the highest level of healers' popularity in this country (Stickley et al. 2013). 
" $89 \%$ of patients who visit the Psychotherapeutic Clinic and approximately I00\% of patients in the other mental health wards of the Kyrgyz Republic Center of Mental Health have met traditional healers prior to seeking psychotherapy" (Molchanova, Kim et al. 2009, 267) 25.

The authors admit that what they call "Kyrgyz folk psychotherapy" is more popular among the Kyrgyz people than official psychotherapy. They state that the help-seeking behaviour of the Kyrgyz is predictable: "the first (and often the last) person they would like to see is a traditional healer" (Molchanova, Kim et al. 2009, 270).

It is noteworthy that a group of psychiatrists collaborated for some time with the Aigine Cultural Research Centre in Bishkek, whose mission is to revive and enhance Kyrgyz cultural traditions ${ }^{26}$. They took part in expeditions organised by Aigine to sacred sites in several regions of Kyrgyzstan and had an opportunity to talk with healers and observe their practices, often conducted in mazars, since healing proceeded there is considered most effective (Adylov 2007; Tulebaeva 2009). During that research the participants interviewed local people and, for instance, the results of a survey done in the Talas oblast (administrative region) showed a high level of people's trust in healers and their capability to contact spirits of the dead (Molchanova et al. 20II, 38). Psychiatrists were also invited to participate in the activities of a special commission created by the Ministry of Health in I990s, which worked at the "Beyish" Centre of Folk Medicine with the aim to select healers with extraordinary abilities, who then received some additional training at the Centre ${ }^{27}$. These encounters certainly influenced perceptions and attitudes of this group of psychiatrists to Kyrgyz traditional healing.

Duyshenkul Adylov, a "very talented psychiatrist", as Galina Mikhailovna, the older of my interlocutors, called him, was the first to start researching Kyrgyz healers. She added that it was just at the beginning of perestroika, so

"our brains were designed and oriented at Marxist-Leninist ideology. [Therefore] we thought that a very large percentage of healers were unhealthy".

In Adylov's book, already published (in Russian) in 1999, entitled Psychiatric and Psychotherapeutic Aspects of Healing in Kyrgyzstan, he presented the results aIo-year study of various types of Kyrgyz healers, altogether 358 persons. He used methods of psychiatry, striving to reveal those who suffered from mental illness and, as a result, he found 40 people among the healers with severe psychotic disorders and a number of individuals

25 This survey was conducted in all wards of the Republican Centre of Mental Health in 2005 and 2006.

26 http://www.aigine.kg/?lang=en. Access: I2.IO.2018. The Director of Aigine, Gulnara Aitpaeva and her colleagues published several books - collections of articles based on interdisciplinary research on sacred sites and healing in Kyrgyzstan.

27 I write more about the "Beyish" Centre in another article (Penkala-Gawęcka 20I8) - its years of prosperity, then crisis and, finally its dissolution - which reflects the changing political and socioeconomic conditions. The psychiatrists who were my interlocutors also briefly participated in the commission mentioned above, but they were rather sceptical about the value of its activities. 
who had other mental disturbances or neurological problems (Adylov 1999, 88). However, he was also interested in the traits of the healers' personalities and the mechanisms of their influence on patients. He discovered similarities between their techniques and those used by professional psychotherapists, first of all suggestion, and noticed that applying "specific attributes", characteristic of a particular "ethno-cultural context", strengthens psychological influence (1999, 107). The author admitted at the beginning of his book that while he had started his work with healers as a psychiatrist, further studies showed him many elements of their practice which were interesting for a psychotherapist. Adylov tried to catalogue the variety of Kyrgyz healers, and differentiated the following categories: $k u u c h u$ (resembling a shaman) and bakshy (a shaman - according to the author, strongly Islamised), közü achyk (a clairvoyant), tabyp (tavyp) (uses pulse diagnostics and hot/cold classification of illnesses) and synchy (combines traditional Kyrgyz and extrasensory methods) ${ }^{28}$ (Adylov 1999, 80-82, 2007, 38I-383). According to Galina Mikhailovna, Adylov headed the commission responsible for selecting healers at the "Beyish" Centre. Besides, for some time he collaborated with the Aigine Centre and his findings were subsequently quoted by the authors of other publications, including psychiatrists who valued his work. What is worth mentioning, he observed healing séances and asked the healers, among other things, about their motivation behind the decision to practise and tried to obtain detailed accounts of their way into the healing profession.

Adylov and then other psychiatrists became particularly interested in the phenomenon of the emergence of a future healer. For specialists, the problem of differentiation between those healers who have psychiatric disorders and the others was crucial, and they tried to develop differential diagnosis (Adylov 1999, 36-43). However, they noticed the strength of local beliefs about the appointment of the healer by spirits, and a specific illness which marks such predestination. This is a variant of the "shamanic illness", well known from ethnographic accounts, not only in Central Asia, but also in many other regions. Anthropologists working in Central Asia point to the importance of a "shamanic/healer's illness" in the career of contemporary spiritual healers (e.g. Biard 2013; Penkala-Gawęcka 20I3; Pelkmans 2017). Such sufferings are usually taken (especially when supported by the authority of an experienced healer) as a sign of the call of spirits, ancestor spirits in particular, choosing a person who should become a healer. If someone who has been appointed does not want to accept this calling, he or she would be punished with further suffering or even death. So, this specific illness

28 Other types of healers are also presented in the literature, e.g. bübü, described as a female shaman. Ethnographic research shows that the terminology is not stable and healers often do not overtly name their specialty. Pelkmans (2017, 152) for example, claims that Kyrgyz healers do not call themselves bakshi mainly because they do not aspire to be like the great, powerful shamans living in the past. For a discussion on Kyrgyz spiritual healers' initiation, sources of legitimacy and authority see PenkalaGawęcka (2017a, 24-29). 
is treated as the result of misapprehension or disobedience of the person chosen by spirits (Molchanova, Aytpaeva et al. 2009, 209).

Psychiatrists from the discussed circle have also used and elaborated the concept of kyrgyzchylyk (Kyrgyzness), which was popularised by members of organisations engaged in reviving the Kyrgyz cultural heritage, especially Aigine Cultural Research Centre. This concept, also described in contemporary ethnographic accounts, is characterised by Aitpaeva and Molchanova as "the totality of characteristics and qualities inherent to the Kyrgyz ethnic group" $(2007,395)$. In this sense, it can be understood as a culturally defined Kyrgyz national identity, which is closely connected with musulmanchylyk (Muslimness) (Toktogulova 2007) ${ }^{29}$. At the same time, this term is used in a narrow sense too - according to the authors, people relate it to various forms of spiritual healing and clairvoyance, which require possessing supernatural abilities. Such extraordinary individuals are treated as "having a gift of kyrgyzchylyk"30 (Aitpaeva and Molchanova 2007, 398). In the article referred to above, Molchanova tried to explain this phenomenon from the standpoint of transpersonal psychology. But in the other, later text (Molchanova and Agazade 2016, 276-277) the authors interpret kyrgyzchylyk as connected with a psychotic episode - a kind of "pre-kyrgyzchylyk", with hallucinations and dissociative signs, namely what is called in ethnographic literature the "shamanic/ healer's illness". The psychiatrists notice, however, that because of widespread ideas about the call of spirits, "an initial psychotic episode is usually considered a 'spiritual emergence', and a patient generally has to visit a number of traditional healers before a psychiatrist takes care of him or her" (Molchanova, Kim et al. 2009, 270).

\section{PSYCHIATRISTS AND HEALERS - MUTUAL RELATIONS AND ATTEMPTS AT COOPERATION}

Existing evidence confirms the great popularity of traditional healers in various parts of the world, where they often act as strong rivals or significant partners of biomedical professionals in the local contexts of medical pluralism. Such situations prompt a search for some forms of "peaceful coexistence" or even cooperation with non-professional practitioners. Transcultural psychiatry, concerned with the relationship between culture and mental health, has made significant efforts directed towards rapprochement between psychiatrists and healers. The classic work of E. Fuller Torrey (1972) is a good example of this approach. He showed that shamans or witch doctors

29 Irina Antonovna, the younger of the psychiatrists I talked to, expressed her fear that the idea of kyrgyzchylyk would acquire a chauvinistic tinge.

30 One of the variants of kyrgyzchylyk is manaschylyk, i.e. a special gift of telling the great Kyrgyz epic "Manas". Manas tellers are considered, similar to healers, persons chosen and led by spirits, and their initiation has similar characteristics. 
can sometimes be as effective or even more effective than psychiatrists, and revealed similarities in methods and techniques used by both parties ${ }^{31}$.

Attitudes of psychiatrists and other biomedical professionals to local traditional healers in post-Soviet Central Asia varied, depending on many factors. Latypov showed that although in Tajikistan mental health care was in a "dormant" phase, representing "the widespread neglect of mentally ill people" (Latypov 20I0, 444) and healers had been extremely popular, psychiatrists and other medical personnel were overtly hostile towards them. In Shymkent (southern Kazakhstan), Botagoz Kassymbekova noted a different approach in a similar situation of distrust of psychiatrists and authority of healers among people with mental health disorders:

"Doctors (...) often shunt "no-hope cases" off to healers. They view taeyips as a cultural tradition that people in Shymkent and other communities created, protect, and are comforted by. Some even suggest that taeyips should consider getting formal training, so they can offer more professional help" (Kassymbekova 2003, 4).

My observations from Kazakhstan, where I did research in the second half of the I990s, revealed that a number of psychiatrists and other physicians who had contact with healers at the centres of complementary medicine in Almaty, tended to accept their abilities and they even included some of the healers' treatment methods into their own practice (Penkala-Gawęcka 20I8, 60-6I).

Obviously not all psychiatrists and psychologists in Kyrgyzstan appreciate the practices of traditional spiritual healers ${ }^{32}$. Adylov pointed to the "confusion" of the majority of doctors, including psychiatrists, whose lack of knowledge and experience, together with inflexibility, hindered the understanding of the role of healers in the society (Adylov 1999, 23). In his later article he argues that in the early post-Soviet period, representatives of official medicine experienced a kind of "cultural shock" when they observed the expansion of healing, however the perspective of many specialists has changed then (Adylov 2007, 379). According to the opinions of the psychiatrists I talked to, healers can help in specific cases ${ }^{33}$. Irina Antonovna, the younger of my interlocutors, said that among the healers whom she had met, several had easily visible signs of

3I An example of a newer publication that focuses on integration of traditional healing with psychiatric treatment in various regions of the world, is the book entitled Psychiatrists and Traditional Healers (Incayawar et al. eds. 2009).

32 The attitude of biomedical professionals in Kyrgyzstan to traditional healing seems varied, but perhaps most of them tend to deny their practices and treat the majority of healers as charlatans (see Pelkmans 2017). On the other hand, such segments of complementary medicine as acupuncture or apitherapy, which are mainly practised by physicians, are accepted and officially supported.

33 Similarly, psychologists who conducted research on healers in the north of Kazakhstan have argued that their methods were effective in diverse neurotic and psychosomatic disorders (Jumageldinov et al. 2015, 209). 
mental illness, but some, possibly, had a kind of special gift. In her opinion, a psychiatrist and a healer may complement each other. Galina Mikhailovna mentioned that she is not a "categorical" psychiatrist who would deny any unconventional methods. She also gave an example of a "very reasonable" healer who was trained in western psychotherapy, and although she did not use it in her practice, in Galina's words this knowledge might somehow help her.

Molchanova, Kim et al. have wondered what the future of psychotherapy in Kyrgyzstan would be:

\footnotetext{
"There have been movements to render the official mental health service the dominant approach in Kyrgyz society and relegate traditional healing practice to the past. Given the popularity of traditional healing in Kyrgyzstan, however, this seems to be an impossible aim for the near future" (Molchanova, Kim et al. 2009, 276).
}

As I mentioned earlier, some traditional methods have already been used in counselling in Kyrgyzstan. The authors maintain that there is "a unique prototype of Kyrgyz psychological counseling, which is a product of both psychotherapy and traditional healing" (Molchanova, Kim et al. 2009, 276). Besides, a portion of psychiatrists claim that certain aspects of folk healing may be included in psychiatric practice. Adylov writes that presently

"those medical doctors, who discovered the rational[e] in folk healing practice, adopt its elements in their work. Some of them are practising even at mazars. (...) Folk healing can add [supplement] treatment with natural elements, culturally sensitive social and rehabilitation activities in therapeutic practices" (Adylov 2007, 379).

He emphasises the similarities between particular healers' practices and psychotherapeutic techniques, for example hypnosis (Adylov 2007, 390). Other specialists also recommend appreciating the "positive aspects" of folk healing and using them in mental healthcare. They notice, however, that this should be done with caution, because, for example, if a psychiatrist would like "to use the rhythmic knocks of an asatayak (special stick) in therapy, he or she may not be taken seriously" (Molchanova, Kim et al. 2009, 276).

In this context, my interlocutors mentioned the Medical Centre of Dr. Nazaraliev, the largest private psychotherapeutic institution in Kyrgyzstan, specialising in alcohol and drug addiction treatment. In his book entitled Fatal Red Poppies, Zhenish Nazaraliev refers to the achievements in substance abuse therapy, which was developed by local psychiatrists and implemented for the first time in the Soviet Union (Nazaraliev 2003, 73-74), however, he focuses then on a search for his own methods of treatment. In his words, what he invented is a "highly scientific method of psycho-pharmaceutical treatment", patented by the Centre. The core of this approach is a "deep-level psychotherapy" (or stress-energetic psychotherapy, shock therapy) (Nazaraliev 2003, 82). 
The Nazaraliev Medical Centre has substantially developed and now consists of two big facilities in Bishkek and its vicinity (the second building, a rehabilitation unit, is located in the foothills of Tian Shan). They have two departments: one of narcology and the other one of psychiatry. Treatment is divided in three stages: detoxification (psychopharmacological therapy), "mindcrafting" and a "powerful finale" called stress energetic psychotherapy ${ }^{34}$. The Centre's website claims that "yearly remission success rate for drug addicted patients is $83 \%$ and alcohol addicted patients is $92 \% " 35$.

Interestingly, Nazaraliev and his personnel have included some elements of Kyrgyz traditions into the second stage - "mindcrafting". This method is presented as

"a psychotherapeutic synthesis of eastern spiritual and philosophical approaches to medicine and western pragmatic scientific techniques".

As we can read on the site:

"just above the rehabilitation facility, on the mountain of salvation called 'tashtar-ata', a handmade pile of stones and four pagodas (Christian, Muslim, Buddhist and of Judaism) have found its accommodation" 36 .

However, these "pagodas" have apparently been added later, when the circle of international clients of the Centre widened. Earlier, as the above-mentioned book suggests, more stress was put on Kyrgyz traditions, with Tashtar-Ata treated as their sacred mountain. During the rehabilitation, patients climbed up the mountain and, "in keeping with local traditions" took stones with them and later left them on the pile. They also "left behind them (...) 'ribbons of hope' tied to the bushes at the summit" (Nazaraliev 2003, 385). This was obviously related to the old tradition, still alive in Central Asia, of fastening cloth ribbons to tree branches and making a wish (see Montgomery 2007). Galina Mikhailovna stressed that in this context the reason for this practice was "to tie up the addiction", get rid of it. These practices formed a part of the programme called "The Seventh Sky", whose results, according to Molchanova, Kim et al., were "very encouraging" (2009, 273). Today, stones are still used during the "ritual of liberation" on Tashtar-Ata, and this procedure is named "lapidopsychotherapy". The use of stones is presented as a "transcultural ritual". Besides, mindcrafting includes living in traditional, "comfortable handmade yurts" near the beautiful Issyk-kul lake, using the Russian sauna (bania) and practising meditation, as well as "Dervish dance" and "Aum $[\mathrm{Om}]$ chanting" 37 .

34 As explained, it includes elements of imperative influence and neurolinguistic programming.

$35 \mathrm{http} / /$ nazaraliev.com/en. It should be added that this treatment is available only to well-off patients and, in addition, also VIP services are offered: http://nazaraliev.com/en/pricing-policy. Access: I3.II.2OI8.

36 http://nazaraliev.com/en/treatment-and-rehabilitation. Access: 13.II.20I8.

37 http://nazaraliev.com/en/treatment-and-rehabilitation. Access: I3.II.20I8. Such hybridisation of methods and techniques is also characteristic of complementary medicine in today's Central Asia. 
A possible rapprochement of traditional healing and official psychiatry and psychology is also seen from the different angle. In the opinion of some psychiatrists, a solution might be the acceptance of parallel interventions of psychiatrists (or psychologists) and healers. The former can remove symptoms of illness, while only the latter - according to the prevailing illness aetiologies - are able to fight a deep, hidden cause of health disorder. In fact, patients often seek help from both traditional healers and doctors. This kind of parallel treatment, according to specialists, may be especially effective in the case of non-psychotic patients "with a traditional worldview" (Molchanova, Aytpaeva et al. 2009, 215; Molchanova, Kim et al. 2009, 276). In addition, psychiatrists point out that healers usually refer patients to medical doctors when they recognise serious psychotic symptoms whose treatment is beyond their competence (Adylov 2007, 391; Molchanova, Kim et al. 2009, 27I).

The attitude of the same group of psychiatrists to traditional spiritual healers seemed to become even more positive after the bloody ethnic clashes between the Kyrgyz and Uzbeks in the south of Kyrgyzstan, in 20I0. Medical professionals and psychologists worked as members of teams established in order to help the survivors of these events. As I mentioned before, the specialists recognised difficulties in diagnosing people who apparently suffered from post-traumatic stress disorder. Because of locally shared beliefs about the causes of their sufferings, patients preferred to ask for help a traditional healer rather than go to a psychiatrist. Medical professionals noticed that "culturally-shaped features of stress disorders" among the Kyrgyz decrease the effectiveness of psychiatric treatment. In the face of this, they advised using local mediators between patients and psychiatrists and establishing an "effective communication between traditional healers and mental health professionals" (Molchanova and Agazade 2016, 277).

Further experiences, connected with assistance provided to the victims of genderbased violence during the Osh and Jalal-Abad events, also showed that cooperation between the two parties is possible. In a very interesting article based on encounters with the local healers and their patients, Molchanova et al. (2017) reveal why these practitioners were so often asked for help in such cases, and explain the causes of their effectiveness. In accordance with the shared cultural norms, raped women tried to hide their "shame", therefore the majority of survivors preferred not to seek psychiatric or psychological help. The authors write:

"taking into consideration the cultural context, victims of GBV [gender-based violence] often are more likely to look for assistance from traditional healers than from crisis centers" (Molchanova et al. 2017, 8).

The examples from their field research illustrate the approach of healers, who are thoroughly familiar with the worldview and social constraints experienced by their patients. The sufferings of those survivors who had signs of sleep paralysis or difficulties in breathing at night were usually interpreted as albarsty's visits and traditional 
healers - bubu (bübü) or kez-achyk (közü achyk) - were considered competent in those cases. Healers often saw victims of gender-based violence who had "unexplained bodily symptoms", such as pains in various parts of the body, which psychiatrists called "somatoform symptoms". In one such case, quoted in the article, the bubu suspected that her patient had been raped in 20IO, which she had subsequently hidden from her husband and his family. The healer told the kelyn's mother-in-law that her illness was caused by korkun (great fear) and performed special purifying rituals. In addition, "the bubu did not take any money from the young woman and told her mother-in-law that it was an honor for her to see such a 'clear soul' in the young kelyn", which resulted in much better treatment of the woman from her husband's relatives (Molchanova et al. 2017, 9).

The authors conclude that due to socio-cultural factors, consequences of genderbased violence in Kyrgyzstan often remain beyond the reach of the mental healthcare professionals. Therefore, as they claim, "psychiatry, unlike other medical specialties, might greatly benefit from cooperation with traditional healing, and patients with stress-related disorders can receive help from a wise traditional healer" (Molchanova et al. 2017, 8).

\section{CONCLUDING REMARKS}

The fact of the great popularity of healers, especially traditional spiritual healers, among the inhabitants of Kyrgyzstan, which has been observed since the r990s, certainly influences the attitudes of biomedical professionals to their practices. It is apparent that the position of doctors towards their non-biomedical rivals is mostly negative, although it differs depending on the kind of complementary medicine practice. Nonetheless, they tend to enhance the boundaries between biomedicine and "folk" medicine and often treat healers as charlatans (Penkala-Gawęcka 20I8). The perspective of psychiatrists, discussed in this paper, is different. At least a portion of them take into account the importance of people's deep distrust of psychiatrists and psychiatric institutions, marked by strong negative emotions, which hinders the effectiveness of mental healthcare. For example, Adylov points out that the commonly shared negative image of psychiatrists and their abilities makes healers' services more attractive (Adylov 1999, I8). Stigmatisation of persons with mental disorders is among the often quoted reasons for people's avoidance of psychiatric assistance, especially in the villages (Molchanova et al. 2017, 8; Kanev 2012, 7; Sadykov and Hosák 20I6, 35). Various problems of mental healthcare in Kyrgyzstan (organisational deficiencies, underfunding, insufficient and uneven distribution of specialists), presented in the first part of the article, create further barriers to the access to professional help. 
However, in my opinion the most important element is the shared worldview of traditional healers and their clients, particularly their beliefs concerning the spiritual world and illness aetiologies. In addition, Kyrgyz healers are fully competent in local cultural values and norms, hierarchies in the extended family and clan structure, gender roles, etc. In fact, as members of the local Kyrgyz communities, they are "culturally sensitive". These factors have been noticed by the psychiatrists; for example Molchanova et al. write that a healer may be effective because he/she "can operate in the same cognitive schema as his/her patient by mixing traditional rituals, prayer and cognitive behavioural techniques, even while a healer is unaware of using them" (Molchanova et al. 20I7, 4). As I tried to show, in this context, and especially in critical circumstances such as the consequences of tragic events in the south of Kyrgyzstan in 20IO, some form of cooperation with traditional healers has become a vital issue for the local psychiatrists. It might be argued that pragmatic goals have prevailed over radical differences in "cognitive schemes" and ontologies of psychiatrists and healers. What is apparent is that the former quite often refer to the similarities between a number of professional psychotherapeutic techniques and healers' practices, which may be seen as a kind of self-justification.

In the opinion of local psychiatrists, global standards offered by external specialists often turn out to be inadequate and lack the necessary cultural sensitivity. When appealing for effective measures in dealing with patients who suffer from PTSD, Molchanova and Agazade mention, among others, "training of visiting specialists on cultural competence, including, primarily, respect and loyalty towards representatives of other cultures" (Molchanova and Agazade 2016, 277). Evidence of an appreciative attitude of psychiatrists in Kyrgyzstan towards traditional healers and efforts aimed at cooperation with them, presented in this article, demonstrate how globally promoted ideas about community-based and culturally sensitive treatment and rehabilitation of people with mental disorders can be adopted to local socio-cultural conditions. 


\section{BIBLIOGRAPHY}

A d yl ov D. U. 1999. Psikhiatricheskie i psikhoterapevticheskie aspekty tselitel'stva v Kyrgyzstane. Bishkek. Ad ylov D. 2007. Healing at Mazars: Sources of Healing, Methods of Curative Impact, Types of Healers and Criteria of Their Professional Qualifications. In G. Aitpaeva, A. Egemberdieva, M. Toktogulova (eds.), Mazar Worship in Kyrgyzstan. Rituals and Practitioners in Talas. Bishkek, 377-394.

A i t p a e va G. 2006. The Phenomenon of Sacred Sites in Kyrgyzstan: Interweaving of Mythology and Reality. In T. Schaaf, C. Lee (eds.), Conserving Cultural and Biological Diversity: The Role of Sacred Natural Sites and Cultural Landscapes. Paris, II8-I23.

Aitpaeva G. and Molchanova E. 2007. Kyrgyzchylyk: Searching between Spirituality and Science. In G. Aitpaeva, A. Egemberdieva, M. Toktogulova (eds.), Mazar Worship in Kyrgyzstan. Rituals and Practitioners in Talas. Bishkek, 395-4II.

Ald a ke ev a G. 2009. Rol' i mesto dukhov predkov v kul'turnoy zhizni kyrgyzov. In G. Aytpaeva and A. Egemberdieva (eds.), Svyatye mesta Issyk-Kulya: palomnichestvo, dar, masterstvo. Bishkek, 256-265.

A ron s on P. 2007. Rejecting Professional Medicine in Contemporary Russia. Vestnik. The Journal of Russian and Asian Studies 6. https://geohistory.today/rejecting-professional-medicine-russia/. Access: 2.12.2018.

B i a rd A. 2013. Interrelation to the Invisible in Kirghizistan. In T. Zarcone and A. Hobart (eds.), Shamanism and Islam: Sufism, Healing Rituals and Spirits in the Muslim World. London, 79-94.

B orowitz M. and Atu n R. 2006. The Unfinished Journey from Semashko to Bismarck: Health Reform in Central Asia from I99I to 2006. Central Asian Survey 25 (4), 419-440.

Dobryakov I.V., Molchanova E.S., Latipova K. 20I2. Etnokulturnye osobennosti depressiy i ispol'zovanie tradicionnykh ritualov beremennymi zhenshchinami Kyrgyzstana. Psikhicheskoe zdorov'e I (68), 43-48.

Dubu is s on E.-M. 2017. Living Language in Kazakhstan: The Dialogic Emergence of an Ancestral Worldview. Pittsburgh.

D u y s h e m b i y eva J. 2005. Kyrgyz Healing Practices: Some Field Notes. The Silk Road 3(2), 38-44. http://www.silk-road.com/newsletter/vol3num2/8_duyshembiyeva.php. Access: 7.06.2016.

Fi eld M. G. 2002. The Soviet Legacy: The Past as a Prologue. In M. McKee, J. Healy, J. Falkingham (eds.), Health Care in Central Asia. European Observatory on Health Care System Series. Buckingham, Philadelphia, 67-75.

Guidance for Commissioners of Rehabilitation Services for People with Complex Mental Health Needs 20I6. The Joint Commissioning Panel for Mental Health. https://www.jcpmh.info/wp-content/ uploads/jcpmh-rehab-guide.pdf. Access: I2.II.20I8.

Ho h m a n n S. 2007. Les "médicins-tabib", une nouvelle catégorie d'acteurs thérapeutiques en Ouzbékistan post-soviétique? Autrepart. Revue de sciences sociales au Sud 42, 73-90.

$\mathrm{Hohmann}$ S. 20Io. National Identity and Invented Tradition: The Rehabilitation of Traditional Medicine in Post-Soviet Uzbekistan. The China and Eurasia Quarterly Forum 8 (3), I29-I48.

Ibraimova A., Akkazieva B., Ibraimov A., Manzhieva E., Rechel B. 2orra. Kyrgyzstan. Health System Review. Health Systems in Transition I3 (3), I-I52.

Ibraimova A., Akkazieva B., Murzalieva G., Balabanova D. 2orrb. Kyrgyzstan: A Regional Leader in Health System Reform. In D. Balabanova, M. McKee, A. Mills (eds.), “Good Health at Low Cost" 25 Years on. What Makes a Successful Health System? London, II7-I57.

In cay aw a r M., Wintrob R., B o u chard L., B a r to cci G. (eds.). 2009. Psychiatrists and Traditional Healers: Unwitting Partners in Global Mental Health. Chichester. 
Jumageldinov A. N., Nuradinov A.S., Aitysheva A. M. 20I5. Ethnopsychothérapie traditionelle au Kazakhstan: techniques interculturelles de guérison basées sur le chamanisme et l'Islam. In O. Meunier (ed.), Cultures, education, identité. Recompositions socioculturelles, transculturalité et interculturalité. Arras, 199-210.

Kanev K. 2012. An Evaluation of the Mental Health and Society, Kyrgyzstan. For the Open Society Institute. http://www.mhealth.in.kg/MHS-evaluation.doc. Access: IO.IO.20I8.

K a s s y m b e k ova B. 2003. Turning to the Taeyip. Transitions Online, https://www.opensocietyfoundations.org/sites/default/files/mdap_tol_kazakh.pdf. Access 4.08.20I7.

Kle in m an A. and B en s on P. 2006. Anthropology in the Clinic: The Problem of Cultural Competency and How to Fix It. PLoS Medicine 3(I0), I673-1676. https://journals.plos.org/plosmedicine/ article?id=I0.1371/journal.pmed.0030294. Access: I2.06.2018.

Kill a s p y H. 2006. From the Asylum to Community Care: Learning from Experience. British Medical Bulletin 79-80 (I), 245-258.

Latyp ov A. 20I0. Healers and Psychiatrists: The Transformation of Mental Health Care in Tajikistan. Transcultural Psychiatry 47 (3), 4I9-45I.

Lat y pov A. B. 20II. The Soviet Doctor and the Treatment of Drug Addiction: "A Difficult and Most Ungracious Task”. Harm Reduction Journal 8 (32), https://harmreductionjournal.biomedcentral. com/articles/IO.II86/I477-7517-8-32. Access 5.IO.2018.

L a t y p ov A. 2015. Soviet Psychiatry and Drug Addiction in Central Asia. In M. Savelli and S. Marks (eds.), Psychiatry in Communist Europe. Basingstoke, 73-92.

Marks S. and Savelli M. 2015. Communist Europe and Transnational Psychiatry. In M. Savelli and S. Marks (eds.), Psychiatry in Communist Europe. Basingstoke, I-26.

Mental Health Law of the Kyrgyz Republic and Its Implementation. 2004. Mental Disability Advocacy Center. Budapest. http://www.mdac.info/sites/mdac.info/files/English_Mental\%2oHealth\%2oLaw \%20of\%20the\%20Kyrgyz\%20Republic\%20and\%20its\%2oimplementation.pdf. Access: 20.10.20I8.

M i ch a els P. A. 2003. Curative Powers: Medicine and Empire in Stalin's Central Asia. Pittsburgh.

Molch a nova E. 20I4a. Mental Health Rehabilitation in the Kyrgyz Republic: Official and Indigenous Models. Journal of Psychosocial Rehabilitation and Mental Health I (I), 23-26.

Molch a n o va E. S. 20I4b. Postraumatic Stress Disorder and Acute Stress Disorder in DSM-V: Changes and Challenges. Medical Psychology in Russia I (24). http://www.mprj.ru/archiv_global/20I4_I_24/ nomero6.php\#english. Access: 6.II.20I8.

Molchanova E. and Agazade N. 20I6. Cultural Aspects of PTSD (Kyrgyzstan Experience). In N. Agazade and E. Molchanova (eds.), Mental Health in Emergencies and Crises. Guidelines for Emergency Responses. Bishkek, 272-278.

Molchanova E.S., Aytpaeva G.A., Ten V.I., Koga P.M. 2009. Tselitel'stvo i ofitsial'naya psikhiatriya Kyrgyzskoy Respubliki: vozmozhnosti vzaimodeystviya. In Kharitonova V. I. (ed.), Problemy sokhraneniya zdorov'ya v usloviyakh Severa i Sibiri: Trudy po medicinskoy antropologii. Moskva, 204-2I7.

Molchanova E., Horne S., Kim E., Yarova O. 2017. Hybridized Indigenous Healing in the Kyrgyz Republic: Helping Survivors of Violence, Women \& Therapy online, I-I4. http://www. tandfonline.com/doi/full/I0.1080/02703149.2017.1324187. Access: 30.10.2017.

Molchanova E., Kim E., Galako T. 20I5. Psychiatry in the Kyrgyz Republic: In between the Soviet Past and a Vague Future. In D. Bhugra, S. Tse, R. Ng, N. Takei (eds.), Routledge Handbook of Psychiatry in Asia. Abingdon, New York, II-I7. 
Molchanova E., Kim E., Horne S., A itpaeva G., Ashiraliev N., Ten V., Pohilko D. 2009. The Status of Counseling and Psychology in Kyrgyzstan. In L. H. Gerstein, P. P. Heppner, S. Ægisdóttir, S-M. A. Leung, K. L. Norsworthy (eds.), International Handbook of Cross-Cultural Counseling: Cultural Assumptions and Practices Worldwide. Los Angeles, London, New Dehli, $265-277$.

Mo n tg o m e r y D. W. 2007. Namaz, Wishing Trees and Vodka: The Diversity of Everyday Religious Life in Central Asia. In J. Sahadeo and R. Zanca (eds.), Everyday Life in Central Asia: Past and Present. Bloomington, 355-370.

$\mathrm{N}$ a z a ra li e v J. 2003. Fatal Red Poppies... . Moscow, St. Petersburg.

Pel k m a s M. 2017. Fragile Conviction: Changing Ideological Landscapes in Urban Kyrgyzstan. Ithaca, NY.

Penka la-Gaw ęcka D. 20I3. Mentally Ill or Chosen by Spirits? 'Shamanic Illness' and the Revival of Kazakh Traditional Medicine in Post-Soviet Kazakhstan. Central Asian Survey 32 (I), 37-5I.

Penka la-G aw ę ck a D . 20I4a. Niepewność, ryzyko, zaufanie. System opieki medycznej i jego reformy w postsowieckim Kirgistanie a strategie zdrowotne mieszkańców Biszkeku. Etnografia Polska 58 $(\mathrm{I}-2), \mathrm{I} 35-\mathrm{I} 57$.

Penkala-Gawęcka D. 20I4b. The Way of the Shaman and the Revival of Spiritual Healing in Kazakhstan and Kyrgyzstan. Shaman 22 (I \& 2), 57-8I.

Penkala-Gaw ęcka D. 20I6. Risky Encounters with Doctors? Medical Diversity and Health-related Strategies of the Inhabitants of Bishkek, Kyrgyzstan. Anthropology \& Medicine 23 ( 2), I35-I54.

Penk a la-Gaw ę cka D. 20I7a. Legitimacy and Authority of Complementary Medicine Practitioners in Post-Soviet Kyrgyzstan. The Role and Use of Tradition. Rocznik Orientalistyczny 52 (I), 20-32.

Penkala-Gaw ęcka D. 20I7b. Perceptions of Health and Illness, and the Role of Healers in Kyrgyzstan. Public Health Panorama 3 (I), 80-87.

Penkala-Gawęcka D. 20I8. Enduring or Fragile Cooperations. Complementary Medicine and Biomedicine in Healthcare Systems of Post-Soviet Kazakhstan and Kyrgyzstan. Curare. Journal of Medical Anthropology 4I (I+2), 78-94.

Privratsky B. G. 200I. Muslim Turkistan. Kazak Religion and Collective Memory. Richmond.

Probes L.M., Kouznetsov V., Verbitski V., Molodyi V. 1992. Trends in Soviet and Post-Soviet Psychiatry. The PSR Quarterly: A Journal of Medicine and Global Survival 2 (2), 67-76.

Raikhel E. and Bemme D. 20I6. Postsocialism, the Psy-ences and Mental Health. Transcultural Psychiatry 53 (2), I5I-I75.

S adykov E. and Hosák L. 20I6. Péče o duševně nemocné v Kyrgyzstánu. Česká a slovenská psychiatrie II2 (I), 3I-35.

S a vas S., Ge dik G., C ra ig M. 2002. The Reform Process. In M. McKee, J. Healy, J. Falkingham (eds.), Health Care in Central Asia. European Observatory on Health Care System Series. Buckingham, Philadelphia, 79-9I.

$\mathrm{Sh}$ ields A. and Kabak D. (eds.). 2008. Observance of the Rights of Patients in Mental Health Institutions in Jalal-Abad. Open Society Institute. Public Health Program. Jalal-Abad. https://www. issuelab.org/resources/7528/7528.pdf. Access: I2.II.20I8.

Stickley A., Koyanagi A., Richardson E., Roberts B., Balabanova D., McKee M. 2013. Prevalence and Factors Associated with the Use of Alternative (Folk) Medicine Practitioners in 8 Countries of the Former Soviet Union. BMC Complementary and Alternative Medicine 13 (83), I-9.

Th orn icroft G. and Tansella M. 2003. What are the Arguments for Community-Based Mental Health Care? Copenhagen. http://www.euro.who.int/document/E82976.pdf. Access: I2.05.2019. 
Tok togulova M. 2007. Syncretism of Beliefs (Kyrgyzchylyk and Musulmanchylyk). In G. Aitpaeva, A. Egemberdieva, M. Toktogulova (eds.), Mazar Worship in Kyrgyzstan. Rituals and Practitioners in Talas. Bishkek, 507-518.

To r r e y E. F. 1972. The Mind Game: Witchdoctors and Psychiatrists. New York.

Tu l e b a e va B. 2009. Vera i znanya v praktike tseliel'stva. In: G. Aitpaeva and A. Egemberdieva (eds.), Svyatye mesta Issyk-Kulya: palomnichestvo, dar, masterstvo. Bishkek, 329-340.

WHO-AIMS Report on Mental Health System in Kyrgyzstan. 2008. Bishkek. https://www.who.int/ mental_health/Kyrgyzstan_who_aims_report.pdf?ua=I. Access: I5.IO.20I8.

\section{Author's address}

Danuta Penkala-Gawęcka, PhD Hab.

Institute of Ethnology and Cultural Anthropology

Adam Mickiewicz University in Poznań

ul. Uniwersytetu Poznańskiego 7

6I-6I4 Poznań, POLAND

e-mail: danagaw@amu.edu.pl

ORCID: 0000-0002-3726-3272 